\title{
THE VALIDITY OF BLENDED LEARNING ORIENTED STUDENT WORKSHEETS TO IMPROVE SCIENCE PROCESS SKILLS IN ELECTROLYTE AND NON-ELECTROLYTE SOLUTION MATERIALS
}

\author{
Rachma Devita Santoso ${ }^{1}$, Rusly Hidayah ${ }^{2 *}$ \\ ${ }^{12}$ Program Studi Pendidikan Kimia, Universitas Negeri Surabaya. Jl. Ketintang, Kec. Gayungan, Kota \\ Surabaya, Jawa Timur 60231, Indonesia \\ * Coressponding Author. E-mail: ruslyhidayah@unesa.ac.id
}

Received: 13 January 2021

Accepted: 12 July 2021

Published: 14 August 2021

doi: 10.29303/cep.v4i2.2394

\begin{abstract}
This study aims to determine the validity of student worksheet with blended learning orientation to improve Science Process Skills in electrolyte and non-electrolyte solution material. The method used is Research and Development. Data collection was obtained from three validators in the field of chemistry education using validation sheets. The data obtained were analyzed descriptively quantitatively. This study discusses the validity of the developed Student Worksheets, in terms of content and in terms of constructs. The results based on the validation assessment by the validator obtained very valid results on the content validity and construct validity with the respective percentages of $81.90 \%$ and $85.64 \%$. It is concluded that student worksheet oriented blended learning to improve Science Process Skills in electrolyte and non-electrolyte solution material is valid as a learning medium.
\end{abstract}

Keywords: student worksheets, blended learning, science process skill, validity.

\section{Validitas Lembar Kerja Peserta Didik (LKPD) Berorientasi Blended Learning Untuk Meningkatkan Keterampilan Proses Sains Pada Materi Larutan Elektrolit dan Non Elektrolit}

\begin{abstract}
Abstrak
Penelitian ini memiliki tujuan yaitu untuk mengetahui kevalidan LKPD berorientasi blended learning untuk meningkatkan KPS pada materi larutan elektrolit dan non elektrolit. Metode yang digunakan ialah Reseach and Development. Pengumpulan data diperoleh dari tiga validator di bidang pendidikan kimia dengan menggunakan lembar validasi. Data yang diperoleh dianalisis secara deskriptif kuantitatif. Penelitian ini membahas mengenai validitas LKPD yang dikembangkan, dari segi isi dan dari segi konstruk. Hasil berdasarkan penilaian validasi oleh validator diperoleh hasil sangat valid pada validitas isi dan validitas konstruk dengan persentase masing-masing $81,90 \%$ dan 85,64\%. Disimpulkan bahwa LKPD berorientasi blended learning untuk meningkatkan KPS pada materi larutan elektrolit dan non elektrolit valid digunakan sebagai media pembelajaran.
\end{abstract}

Kata kunci: LKPD, blended learning, KPS, validitas.

\section{INTRODUCTION}

Education is a plan to create attractive learning conditions for students to develop selfcontrol, spiritual skills, intelligence, and manners needed in society, nation and state. The purpose of curriculum development is as a form of adapting the learning curriculum to the characteristics of students, by designing a learning system, determining boundaries, and good and innovative learning quality (Munandar, 2018).

The 2013 curriculum is applied as a form of improvement from the curriculum applied in the previous education world, namely the 2006 curriculum (KTSP). Curriculum changes in the world of education result in changes in the process of implementing learning. The implementation of the 2013 curriculum needs the support of competent educators, the breadth of knowledge they have, the way of thinking, 
and the depth of knowledge that an educator has (Yusutria, 2017). There are three main components in the 2013 curriculum, namely attitudes (affective), skills (psychomotor), and knowledge (cognitive). The implementation of the 2013 curriculum answers the challenges of students in the 21 st century, which requires students to be able to communicate, be critical and innovative, and be able to solve problems.

In an effort to support the implementation of the 2013 curriculum properly in the learning process, students need skills that involve themselves actively, so that learning can become a meaningful learning for students, namely by using Science Process Skills (KPS) (Fitriyani \& Susatyo, 2017). The goal of Science Process Skills is to find concepts, where students are able to develop learning concepts by linking new information or knowledge with previously acquired knowledge (Syaputra, 2016). Science Process Skills plays a role in motivating students to be directly involved in concept discovery (Champlain, 2010). This is because Science Process Skills guides students in developing their existing abilities, so they can process new information quickly and accurately (Semiawan \& Suseloardjo, 1989). Therefore, Science Process Skills needs to be implemented in schools so that students are accustomed to developing the knowledge obtained, discovering new knowledge and concepts from the information obtained, and being able to connect previously owned concepts with new concepts obtained (Tawil \& Liliasari, 2014). In this study, the Science Process Skills components used consisted of identifying problems, formulating problems, making hypotheses, compiling experimental steps, determining experimental variables, writing down observations, analyzing data, and making conclusions (Nur, 2011).

In the 21 st century where technology and information are growing rapidly, it is necessary to update the orientation of learning in schools, one of which is to implement blended learning as a form of learning innovation. Blended learning is a learning method that combines direct learning with online learning (Murniati \& Sanjaya, 2013). Direct learning is carried out like ordinary learning in the classroom, while online learning utilizes easy-to-use NGOs, such as Moodle, Google Classroom, and Edmodo. The application of blended learning is expected to help students improve their existing Science Process Skills by taking advantage of advances in technology and information.
Blended learning needs to be implemented in schools to support the improvement of science process skills, one way is to use student worksheets (LKPD). Student Worksheets generally contains instructions for using Student Worksheets, phenomena, and questions related to the phenomena presented (National, 2008). The development of Student Worksheets is compiled and designed by looking at the learning atmosphere in a school with the characteristics of different students (Rohaeti, 2009).

Based on the background presentation, the developed Student Worksheets needs to be evaluated to determine the content validity and construct validity, with the hope that the Student Worksheets can be used by teachers and students in the learning process to improve student's Science Process Skills. The purpose of this study was to state the validity of student worksheet with blended learning orientation to improve Science Process Skills in electrolyte and nonelectrolyte solution material.

\section{METHOD}

The method used is Research and Development with the Nieveen development model which consists of (1) Preliminary Research and (2) Prototyping Stage (Akker, Den, Plomp, \& Nieveen, 2006), with the object of research is Student Worksheets oriented to blended learning to improve Science Process Skills. The results of improving students' science process skills were determined from the scores obtained in the pretest and posttest carried out. The pretest was carried out before students received treatment in class, namely before the implementation of science process skillsoriented learning with the help of developed student worksheets. Posttest is given after students get treatment in class. Posttest was given to determine the improvement of students' science process skills using the developed student worksheets.

The following is an explanation of the R\&D method by Nieveen (Akker, Den, Plomp, \& Nieveen, 2006).

\section{Preliminary Study Stage}

The purpose of this preliminary study stage is to determine the problems and circumstances in the implementation of learning, especially in chemistry subjects, by identifying learning needs, analyzing the suitability of 
learning models and using appropriate learning tools to support learning.

\section{Development Planning and Prototyping Phase \\ Development Planning}

This stage is the design stage of the draft Student Worksheets oriented to blended learning to improve Science Process Skills.

\section{Validity Evaluation}

The evaluation stage is an activity to test the validity of Student Worksheets based on expert judgment. The validity of the developed Student Worksheets will be assessed by three validators in the field of chemistry. If the data on the validity of the Student Worksheets results in valid to very valid criteria, then the product can be used in the learning process. The instrument used to test the validity of this Student Worksheets was a content and construct validation questionnaire.

The data from the Student Worksheets validation results were analyzed by calculating the percentage of validity, namely the assessment of each indicator was assessed using a Likert scale in the 1-5 range with the assessment categories in Table 1.

Table 1. Skala Likert

\begin{tabular}{cc}
\hline Category & Score \\
\hline Very bad & 1 \\
Bad & 2 \\
Moderate & 3 \\
Good & 4 \\
Very Good & 5 \\
\hline
\end{tabular}

(Riduwan, 2016)

The score obtained is then converted into a percentage to determine the validity level of the Student Worksheets which is developed with the following equation.

Percentage (\%)

$=\frac{\text { The total score of the validation results }}{\text { Criteria score }} \times 100 \%$

Where:

Total validation score: the sum of the scores for each item $\mathrm{X}$ of the number of respondents who answered for each item.

Score criteria: highest score $\mathrm{x}$ number of aspects $\mathrm{x}$ number of respondents.

Then, an interpretation is carried out on the percentage obtained according to the criteria of Table 2.
Table 2. Penilaian Validitas

\begin{tabular}{cc}
\hline Percentage $(\%)$ & Criteria \\
\hline $0-20$ & Invalid \\
$21-40$ & Less valid \\
$41-60$ & Quite valid \\
$61-80$ & Valid \\
$81-100$ & Very valid \\
\hline & (Riduwan, 2016)
\end{tabular}

Student Worksheets is said to be valid if it meets the requirements with a percentage of $\geq$ $61 \%$, so that the developed Student Worksheets can be used as a learning medium.

\section{RESULT AND DISCUSSION}

This study aims to test the validity of the developed student worksheets whether they can be used as learning media or not. The validity assessment was carried out by two experts, namely two chemistry lecturers and one chemistry teacher. Science process skills are skills that regulate scientific methods which include observation, classification, processing data based on initial information from observations, formulating hypotheses, conducting experiments, and making conclusions.

Validity is the accuracy of data on the object of research (Ayona \& Hidayah, 2020). The validation results obtained from three experts in the form of an assessment score using a Likert scale with a score of $1-5$, comments, and suggestions for improvement so that the media can be used as supporting learning in schools. In the validation process, there are two criteria that are assessed, namely in the content and construct aspects. The content validity component consists of: (1) the suitability of the material with $\mathrm{KD}$, (2) the correctness of the substance of the subject matter, (3) the suitability of the Student Worksheets with blended learning, and (4) the suitability of Student Worksheets with Science Process Skills criteria. Meanwhile, the construct validity component includes: (1) Student Worksheets suitability with language criteria, (2) The Student Worksheets suitability with criteria related to presentation, and (3) The Student Worksheets suitability related to graphic. The following is an explanation regarding the validity of the developed Student Worksheets. 


\section{Content Validity}

Content validity is closely related to the truth of a concept applied in learning media in schools (Slamet \& Hidayah, 2010). There are four components of content validity in this study, namely the suitability of the material with $\mathrm{KD}$, the correctness of the substance of the subject matter, the suitability of Student Worksheets with blended learning and the suitability of Student Worksheets with Science Process Skills criteria. The following is an explanation and discussion related to content validity.

\section{Material compatibility with $\mathrm{KD}$}

Based on Table 3, the first component is divided into three indicators, namely the suitability of indicators with $\mathrm{KD}$ which gets a percentage of $86.67 \%$ with very valid criteria, the suitability of material in Student Worksheets with KD gets a percentage of $86.67 \%$ with very valid criteria, as well as facts, concepts and The Student Worksheets image has correctly gotten a percentage of $80 \%$ with valid criteria. The suitability of the material with KD is closely related to the suitability of the material to $\mathrm{KI}$ and learning indicators, where the suitability can be seen through three aspects, namely the completeness, breadth and depth of the material presented (Muslich, 2010). The completeness and breadth of the material presented in the Student Worksheets is adjusted to the objectives and learning indicators for electrolyte and nonelectrolyte solution material. The depth of the material in the Student Worksheets is adjusted to the preparation of learning indicators with KD (Nawarda, 2017).

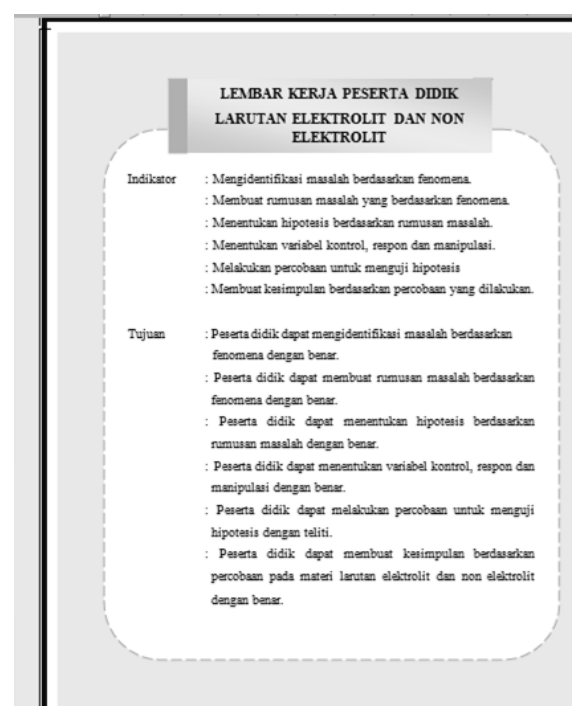

Gambar 1. Indicators and Learning Objectives at Student Worksheets

\section{The Truth of the Subject Matter}

Based on Table 3, the second component is divided into two indicators, namely the accuracy of concepts and definitions, and the accuracy of pictures and illustrations. Both indicators get a percentage of $80 \%$ with valid criteria, which means that the two indicators related to the truth of the material contained in the Student Worksheets are in accordance with the blended learning component to improve Science Process Skills. The truth of the subject matter is the truth or suitability of the Student Worksheets content with the subject matter presented with the aim that students do not experience misconceptions.

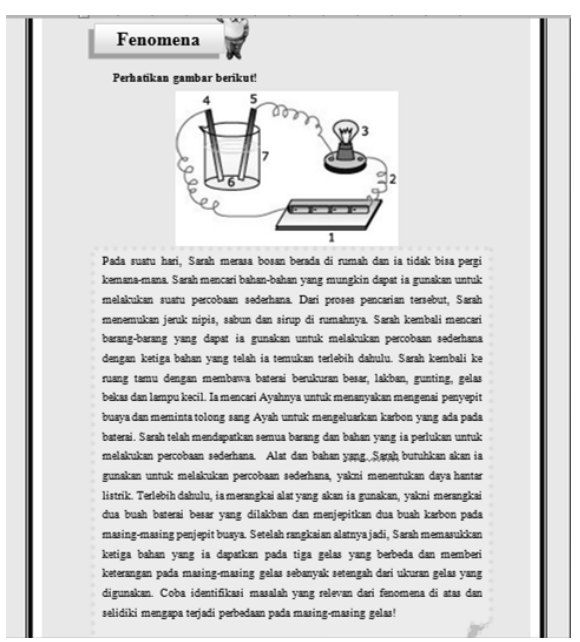

Gambar 2. Phenomenon Presented at LKPD

Blended learning-oriented learning invites students to carry out face-to-face and online learning using one of the NGOs, namely Google Classroom. Blended learning is combined with Science Process Skills with the aim that students actively link learning with phenomena that are often found (Rustaman, 2007). Science Process Skills guides students to be able to acquire new knowledge through practicum activities, and is able to guide students to be able to combine the knowledge obtained with the knowledge they have (Ayd \& Education, 2013).

\section{Suitability of LKPD with Blended Learning}

The blended learning method combines direct learning with online learning. The success of the implementation of blended learning is influenced by the availability of tools and the ease of accessibility which is good enough to support online learning. Most of the learning activities in schools still rely on face-to-face learning (Singh, 2013). 
Student Worksheets is combined with blended learning to provide innovation in the learning process. From Table 3, it is known that the validation results obtained regarding the suitability of Student Worksheets with blended learning obtained a percentage of $80 \%$ with valid criteria, which indicates that the Student Worksheets has been properly used with blended learning orientation. The suitability of Student Worksheets with blended learning is related to how the learning media developed will have a good impact on teachers and students, be able to increase motivation and learning interactions of students, and be able to help students to improve understanding related to the material presented (Arsyad, 2013).

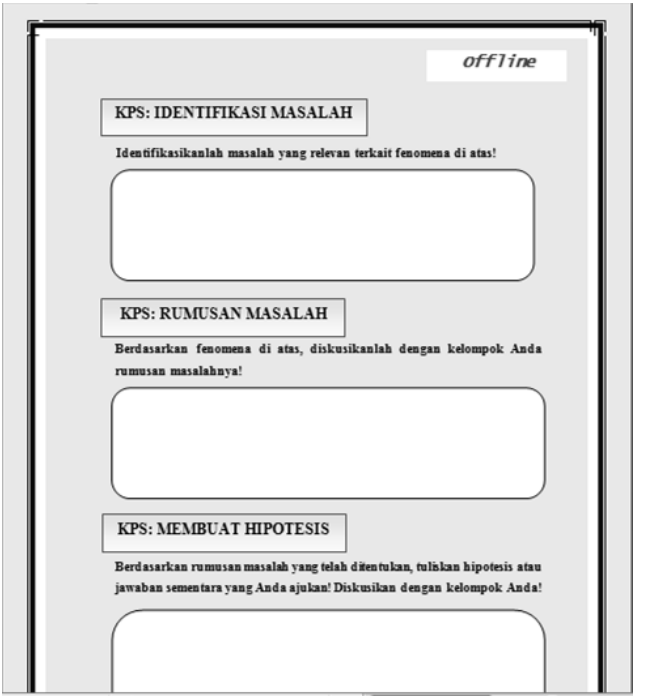

(a)

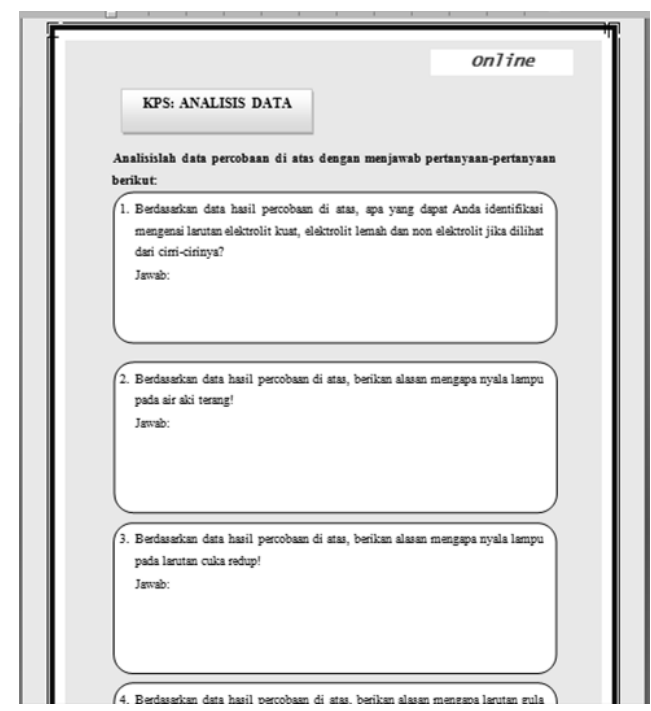

(b)

Gambar 3. LKPD Blended Learning (a) Offline Learning; (b) Online Learning

\section{Student Worksheets Conformity with KPS Criteria}

Science Process Skills is a scientific skill that can train cognitive and psychomotor abilities. Science Process Skills provides opportunities for students in the process of finding facts, concepts, and principles to instill a scientist's soul into students (Risamasu, 2016). The validation results obtained regarding the suitability of Student Worksheets with Science Process Skills criteria obtained a percentage of $80 \%$ in the valid category, which indicates that Student Worksheets can be used to support the improvement of Science Process Skills.

The implementation of Science Process Skills into Student Worksheets is carried out for students to dig up information related to the phenomena presented in the Student Worksheets to find new knowledge. This statement is in accordance with the explanation of the learning theory according to Piaget, which states that communication carried out directly and clearly by presenting it in the form of graphs, tables, diagrams and pictures can improve the thinking and communication skills of students (Tawil \& Liliasari, 2014). Brunner's learning theory also states that discovery learning will help children use their minds to find concepts (Tawil \& Liliasari, 2014).

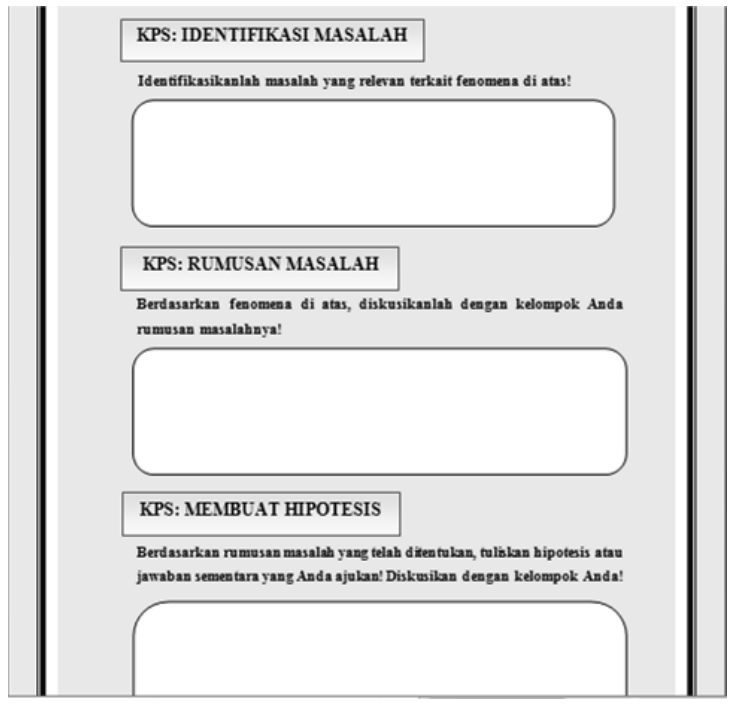

Gambar 4. Science Process Skills at Student Worksheets

\section{Construct Validity}

The following is an explanation and discussion related to construct validity. 


\section{Chemistry Education Practice, 4 (2), 2021 - 176}

Santoso, Hidayah

\section{Student Worksheets conformance with Linguistic Criteria}

The first component is divided into three indicators, namely the use of good and correct language, the language used is short and clear, the sentences do not contain multiple meanings. The three aspects of the components obtained very valid results with all components obtaining a percentage of $86.67 \%$. Based on the percentage of validation results obtained on linguistic criteria, it is known that the use of words and sentences is very valid, which means that the Student Worksheets developed has met the linguistic indicators, because it does not cause multiple meanings (Wulandari \& Rusmini, 2020). Validation of linguistic criteria in Student Worksheets is very important, because the media is a channel of information to the recipient of information, where the intended recipient of the information is students, and in the process of distributing information, good and easy to understand language is needed.

The language of teaching materials must be communicative, sentences must be good and clear, and do not contain double meanings so as not to cause misconceptions in students about the information presented (Kurniawati E. D., 2009). Linguistic criteria in teaching materials are very important for teaching electrolyte and non-electrolyte subject matter so that the material presented is easy to accept, so that direct communication between teachers and students is formed. This statement is in accordance with Ausubel's learning theory, that learning which is influenced by the clarity of knowledge in the field of study can create meaningful learning. The clarity in question is the information obtained by students on communicative learning, so that it can lead to active interaction from students (Harefa, 2013).

\section{Student Worksheets conformity with criteria related to presentation}

In the presentation, the cover used should be attractive and represent the Student Worksheets so that there is a harmony between the cover and the material presented in the Student Worksheets. In Student Worksheets, besides containing phenomena in everyday life, there is also a Science Process Skills component. To support the improvement of Science Process Skills, the developed Student Worksheets needs to provide a place for students to answer the questions presented (Prastowo, 2015).

Based on table 4, the second component is divided into three indicators, namely the cover presents the contents of the Student Worksheets to obtain valid results with a percentage of $80 \%$, there is a place to write answers as needed to obtain very valid results with a percentage of $86.67 \%$, and the completeness of the components presented in the Student Worksheets, consisting of covers with a percentage of $80 \%$, foreword with a percentage of $93.33 \%$, a table of contents getting a percentage of $93.33 \%$, and $\mathrm{KD}$ and indicators getting a percentage of $86.67 \%$. The validation criteria obtained are valid and very valid. Based on the percentage of the assessment, the Student Worksheets developed is in accordance with the criteria (Kurniasih \& Sani, 2014). The Student Worksheets developed is designed to be used independently by students, in this case the teacher only acts as a facilitator. If the Student Worksheets presentation is quite difficult and complicated, then students will have difficulty understanding the material presented (Prastowo, 2015)

\section{The suitability of Student Worksheets related to graphic}

The third component is divided into four indicators, namely image illustrations according to content, use of fonts (type and size) makes it easier to read Student Worksheets, attractive cover design, and layout of text, images and matching tables. The results obtained from the third component are valid on illustrations and layouts with a percentage of $80 \%$, and very valid on the use of fonts and cover designs with a percentage of $86.67 \%$. 


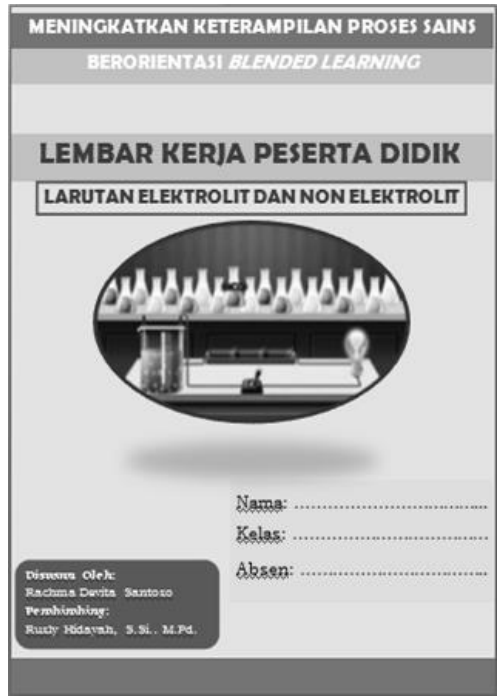

Gambar 4. Main Cover of Student Worksheets

The illustration of the image used in the Student Worksheets must be in accordance with the explanation presented so as not to cause misconceptions to students (Yanti, 2015). The use of fonts must be selected which is attractive and easy to read by using a proportional font size. In order for the Student Worksheets to

\section{CONCLUSION}

Based on the explanation above, it is concluded that the Student Worksheets Oriented Blended Learning to Improve Science Process Skills in Electrolyte and Non-Electrolyte Solution Material developed has met the validity criteria, namely $\geq 61 \%$ with the acquisition of content validity percentage of $81.90 \%$ and construct validity of $85.64 \%$ with very valid criteria. The results obtained indicate that the developed Student Worksheets can be used as a medium of learning in schools.

\section{REFERENCES}

Ayd, A., \& Education, S. (2013). Representation of Science Process Skills in The Chemisstry. International Journal of Education and Practice, 51-63.

Ayona, V., \& Hidayah, R. (2020). Validitas Permainan Chemistry Adventure Berbasis Android Sebagai Media Pembelajaran Ikatan Kimia. UNESA Journal of Chemical Education, 245252.

Champlain, D. (2010). A Primer On Classical Test Theory And Item Response Theory appear more attractive, the layout needs to be considered well (Kurniawati E., 2009).

The developedment of Student Worksheets obtained valid and very valid criteria, which means that the appearance of the Student Worksheets was proportional so that it could be used to study and understand the material presented.

For Assessments In Medical Education. Medical Education.

Fitriyani, R., Haryani, S., \& Susatyo, E. B. (2017). Pengaruh Model Inkuiri Terbimbing Terhadap Keterampilan Proses Sains Pada Materi Kelarutan dan Hasil Kali Kelarutan. Jurnal Inovasi Pendidikan Kimia, 1957-1970.

Harefa, A. O. (2013). Penerapan Teori Pembelajaran Ausubel Dalam Pembelajaran. Majalah Ilmiah Warta Dharmawangsa Edisi 36.

Kurniasih, I., \& Sani, B. (2014). Implementasi Isi Buku Teks Bahasa Indonesia Berbasis Kurikulum 2013. JURNAL Suluh Pendidikan FKIP-UHN, 77-87.

Kurniawati, E. (2009). Pengembangan Bahan Ajar Bahasa dan Sastra Indonesia dengan Pendekatan Tematis. Tesis.

Kurniawati, E. D. (2009). Pengembangan Bahan Ajar Bahasa dan Sastra Indonesia dengan Pendekatan Tematis. Tesis.

Munandar, A. (2018). Pengantar Kurikulum. Yogyakarta: Deepublish.

Murniati, D., \& Sanjaya, I. G. (2013). Pengembangan Perangkat Pembelajaran Kimia Berbasis Blended Learning di 
SMA Negeri 7 Kediri. UNESA Journal of Chemical Education, 133-137.

Muslich, M. (2010). Test Book Writing. Yogyakarta: Ar-Ruzz Media.

Nasional, D. P. (2008). Panduan Pengembangan Bahan Ajar. Jakarta: Departemen Pendidikan Nasional Direktorat Jendral Manajemen Pendidikan Dasar dan Menengah Direktorat Pembinaan Sekolah Menengah Atas.

Nur, M. (2011). Modul Keterampilanketerampilan Proses Sains. Surabaya: Universitas Negeri Surabaya Pusat Sains dan Matematika Sekolah.

Prastowo, A. (2015). Panduan Kreatif Membuat Bahan Ajar Inovatif. Yogyakarta: DIVA Press.

Riduwan. (2016). Skala Pengukuran Variabelvariabel Penelitian. Bandung: Alfabet.

Risamasu, P. V. (2016). Peran Pendekatan Keterampilan Proses Sains Dalam Pembelajaran IPA. Prosiding Seminar Nasional Pendidikan (pp. 73-81). Jayapura: Universitas Cenderawasih.

Rohaeti, T. (2009). Perbandingan Model Pembelajaran Kontekstual dengan Model Pembelajaran Kooperatif dengan Pendekatan Think Pair Share Terhadap Hasil Belajar Siswa pada Mata Diklat Menganalisis Rangkaian Listrik dan Elektronika di SMK Negeri 12 Bandung. Skripsi.

Rustaman, N. (2007). Strategi Pembelajaran Biologi. Universitas Terbuka.

Semiawan, C., A.F, T., S, B., Y, M., \& Suseloardjo. (1989). Pendekatan Keterampilan Proses. Jakarta: PT Gramedia.
Singh, H. (2013). Building Effective Blended Learning Programs. Issues of Educational Technology, 51-54.

Slamet, F., \& Hidayah, R. (2010). Pengembangan Permainan Catch The 3. UNESA Journal of Chemical Education, 695-702.

Sugiyono. (2015). Metode Penelitian Kombinasi. Bandung: Alfabet.

Syaputra, A. (2016). Analisis Perkembangan Aspek Keterampilan Proses Sains Kimia Peserta Didik Melalui Pembelajaran Berbasis Literasi Sains dan Teknologi di SMA Muhammadiyah 11 Padangsidimpuan. Jurnal Eksakta, 4953.

Tawil, \& Liliasari. (2014). Keterampilanketerampilan Sains dan Implementasinya Dalam Pembelajaran IPA. Makasar: Universitas Negeri Makasar.

Wulandari, C. A., \& Rusmini. (2020). Validitas Teoritis LKPD Untuk Mereduksi Miskonsepsi Pada Materi Stoikometri Menggunakan Model Pembelajaran ECIRR Untuk Kelas X SMA. UNESA Journal of Chemical Education, 256274.

Yanti, Y. F. (2015). Pola Penyajian Kegiatan Pembelajaran Bahasa Indonesia Berbasis Pendekatan Ilmiah Dalam Buku Mahir Berbahasa Indonesia SMP/MTs Kelas VII Terbitan Erlangga. Skripsi.

Yusutria. (2017). Profesionalisme Guru Dalam Meningkatkan Kualitas Sumber Daya Manusia. Jurnal Curricula. 